ment is inadequate. As a rough guide for non-surgical cases treatment given over a period equal to the length of the history would in most cases have been adequate.

\section{Summary}

A group of 350 children with urinary-tract infection have been kept under continued surveyance. The infections were not controlled in 28 cases, all of which had major renal-tract abnormalities. The remaining 322 responded to treatment but had a high relapse rate, particularly during the first 18 months after initial control.

During treatment relapses might occur at any time, and many were associated with resistant organisms or the child's failure to take the prescribed medicine or pills. Relapses after treatment had stopped were usually unexplained, but were most likely to occur within the first three months.
Thirteen per cent. of all relapses were associated with upper respiratory infections. Relapses were significantly more frequent during the winter half-year, November to April, than in the summer.

There was some suggestion that for non-surgical cases with a history of over two years' duration anything less than three months' treatment was inadequate.

I would like to thank Professor S. D. M. Court for his help and interest. I am grateful to Mr. R. A. McNay for advice concerning the statistical analysis and to Mrs. M. Jackson for editorial assistance.

\section{REFERENCES}

David, H. A., and Newell, D. J. (1966). Biometrics. In press. Stansfeld, J. M. (1966). Brit. med. F., 1, 631.

\title{
Further Trials of Live Influenza Vaccine*
}

\author{
B. E. ANDREWS, $†$ M.R.C.S., M.C.PATH., DIP.BACT. ; A. S. BEARE, $\ddagger$ M.B., B.CH., M.C.PATH., D.T.M.\&H. \\ J. C. MCDONALD,§\| M.D., M.SC., M.R.C.P., D.P.H. ; A. J. ZUCKERMAN,\$』 M.D., M.SC., M.C.PATH., DIP.BACT. \\ D. A. J. TYRRELL, $* *$ M.D., F.R.C.P., M.C.PATH.
}

Brit. med. F., 1966, 1, 637-640

Small-scale trials of a live influenza $A_{2}$ vaccine in 1960-1 showed that symptomless infections were induced in most subjects, and that despite a rather poor antibody response the volunteers could not be reinfected a month later (McDonald et al., 1962). The vaccine used in these trials was prepared from the Russian $\mathrm{A}_{2}$ strain Iksha attenuated by serial passage in eggs, and was given by drops intranasally. It was therefore pertinent to investigate whether other $A_{2}$ strains would have similar properties if treated in the same way and to investigate whether the vaccine could be given equally well by spray. At the same time we thought it important to determine whether inactivated virus, given intranasally, has any effects (Przesmycki et al., 1959). Vaccines were prepared from the Iksha strain and from a Scottish strain of $A_{2}$ virus, $A / S \cot / 49 / 57$, and their efficacy compared in volunteers.

\section{Technical Procedures}

\section{Preparation of Vaccines and Preliminary Safety Tests}

The live vaccines were prepared in a similar way. The virus was inoculated into the allantoic cavity of 10-day-old chick embryos and these were incubated at $33^{\circ} \mathrm{C}$. for two days. The fluids were harvested and stored at $-70^{\circ} \mathrm{C}$. in glass ampoules. The fluids were tested for the presence of contaminating bacteria by aerobic and anaerobic culture and for viruses (a) by inoculating tissue cultures after mixture with ferret immune serum against $\mathrm{A} /$ Singapore $/ 1 / 57$, and $(b)$ by inoculating into mice by the intracerebral and intranasal route, into guinea-pigs by the

* A report to the Medical Research Council Committee on Influenza and other Respiratory Virus Vaccines.

† Virus Reference Laboratory, Colindale, London.

Epidemiological Research Laboratory, Colindale, London.

** Common Cold Research Unit, Salisbury.

$¥$ Present address, Pfizer Group, Sandwich, Kent.

II Professor of Epidemiology and Health, McGill University, Montreal.

If Seconded from the R.A.F. Medical Services at the time of the trial. Present anpointment: Senior Lecturer, London School of Hygiene and Tropical Medicine, London. intracerebral route, and into rabbits by the subcutaneous route. All the animals remained well. The viruses showed specific haemagglutination-inhibition with ferret immune serum that had been treated with cholera filtrate to remove non-specific inhibitors.

The Iksha strain had been passed six times in ovo and had a titre of $10^{8.2} 50 \%$ egg-infectious doses $\left(\mathrm{EID}_{50} / \mathrm{ml}\right.$.), while the A/Scot/49/57 strain had received about five such passages and had a titre of $10^{9} \mathrm{EID}_{50} / \mathrm{ml}$. A portion of the Iksha virus was inactivated by dialysing it against distilled water and then adding $0.025 \%$ formalin and storing at $4^{\circ} \mathrm{C}$. The virulence for man of the A/Scot/49/57 virus was roughly gauged by administering it in doses of $10^{6}$ and $10^{7} \mathrm{EID}_{50}$ to two groups of four volunteers living in isolation. Three of those given the larger dose developed symptoms, but only one of those given the smaller; it was considered safe to give doses of less than $10^{6} \mathrm{EID}_{50}$ to larger numbers of subjects.

As both the strains gave low titres of inhibition with horse serum, a further strain, A/Eng/443/57, which is very sensitive to inhibitors, was also tested. This produced such marked symptoms in a small group of isolated volunteers that it was not studied further.

The live vaccines were stored in sealed glass ampoules in an electric refrigerator at $-70^{\circ} \mathrm{C}$. until transported to the station on solid carbon dioxide. The vaccine was diluted with Hanks's balanced salt solution containing $0.5 \%$ gelatin $(p H$ about 7.2) immediately before use and kept at $4^{\circ} \mathrm{C}$. until used; this period never exceeded 30 minutes. The dose of vaccine intended for nasal drops was made up to $1 \mathrm{ml}$. with diluent, whereas for spray it was suspended in $0.1 \mathrm{ml}$.

\section{Virus Isolation}

Specimens from nose and throat swabs, prepared as described below, were transported to the laboratory on melting ice, and on the same day $0.2 \mathrm{ml}$. was inoculated into the amniotic cavity 
of three 10-day fertile hens' eggs. Penicillin and streptomycin were added to the inocula in the proportion of 100 units or micrograms respectively per egg. The eggs were incubated at $35^{\circ} \mathrm{C}$. for three days, then after chilling overnight at $4^{\circ} \mathrm{C}$. the amniotic fluids were harvested and tested for agglutination of human and fowl red-blood cells. Positive amniotic fluids were passed as necessary, and the virus was identified by means of a complement-fixation (C.F.) test for influenza-A soluble antigen. Negative fluids were inoculated into a further set of eggs. At one stage, when the supply of eggs broke down, specimens were stored at $-70^{\circ} \mathrm{C}$. until eggs were again available.

\section{Laboratory Methods}

When the trial was first projected it was expected that a pool of approximately 80 volunteers without neutralizing antibody to $A_{2}$ influenza would be required. Previous experience had suggested that the selection of this number would entail the testing of 700-800 sera; the number finally used was in fact 764. While the neutralization technique is appreciably more sensitive than that of haemagglutination-inhibition (Beare, 1962), it is very cumbersome. It was therefore decided to screen all sera at a dilution of $1: 5$ for haemagglutinationinhibiting antibodies and to test only negative sera by neutralization.

Neutralization and Haemagglutination-inhibition Tests.These were performed as previously described (McDonald et al., 1962).

Complement-fixation Tests.-These were performed by the method described by Bradstreet and Taylor (1962), but the conditions for fixation of complement were modified to one and a half hours at $37^{\circ} \mathrm{C}$.

\section{Trial Procedure}

Blood specimens from 764 R.A.F. personnel and 71 civilian employees were screened for neutralizing antibody to $A_{2}$ influenza in September 1962. One hundred and seven (13\%) were without antibody at a serum dilution of 1 in 10 (Table I), and 96 of these volunteered to take part in the trial ; in addition, 98 of those with antibody at this titre agreed to do so.

\begin{tabular}{|c|c|c|c|c|c|c|}
\hline \multirow[b]{2}{*}{$\begin{array}{c}\text { Age- } \\
\text { group } \\
\text { (Years) }\end{array}$} & \multicolumn{2}{|c|}{ R.A.F. } & \multicolumn{2}{|c|}{ Civilians } & \multicolumn{2}{|c|}{ Both } \\
\hline & $\begin{array}{l}\text { No. } \\
\text { Tested }\end{array}$ & $\begin{array}{l}\text { No. } \\
\text { without } \\
\text { Antibody } \\
\text { at } 1 / 10\end{array}$ & $\begin{array}{l}\text { No. } \\
\text { Tested }\end{array}$ & $\begin{array}{l}\text { No. } \\
\text { without } \\
\text { Antibody } \\
\text { at } 1 / 10\end{array}$ & $\begin{array}{l}\text { No. } \\
\text { Tested }\end{array}$ & $\begin{array}{l}\text { No. } \\
\text { without } \\
\text { Antibody } \\
\text { at } 1 / 10\end{array}$ \\
\hline $\begin{array}{l}16-25 \\
26-44 \\
45+\end{array}$ & $\begin{array}{r}448 \\
257 \\
59\end{array}$ & $\begin{array}{l}22(5 \%) \\
44(17 \%) \\
20(34 \%)\end{array}$ & $\begin{array}{r}8 \\
39 \\
24\end{array}$ & $\left.\begin{array}{l}3 \\
9 \\
9\end{array}\right\}(26 \%)$ & $\begin{array}{r}456 \\
296 \\
83\end{array}$ & $\begin{array}{l}25(5 \%) \\
53(18 \%) \\
29(35 \%)\end{array}$ \\
\hline Totals & 764 & $86(11 \%)$ & 71 & $21(30 \%)$ & 835 & $107(13 \%)$ \\
\hline
\end{tabular}

The volunteers were divided into groups, and during October and November were given differing doses of the Iksha or $\mathrm{A} / \mathrm{Scot} / 49 / 57$ vaccines, live or inactivated, by drops or by spray. Four weeks later as many as possible of the volunteers initially without antibody were challenged with a further $10^{4}$ EID $_{50}$ of the A/Scot/49/57 vaccine given by drops. As a control on the potency of the challenging vaccine, 11 volunteers without antibody were held back and given their first dose of vaccine at the same time as the others were given their second dose.

The vaccines were instilled into the nose with a dropper$0.5 \mathrm{ml}$. into each nostril. The volunteer lay with his head overhanging the edge of an examination couch during instillation, and remained there for one minute afterwards. For spraying, the vaccine was loaded into an insufflator and $0.05 \mathrm{ml}$. administered into each nostril with the volunteer sitting up after taking a deep breath and retaining it in maximum inspiration. This latter manœuvre was employed to ensure that the sprayed vaccine was not inhaled deeply during the inoculation.

All volunteers were examined about 36 hours after vaccination and after the challenge dose. Their temperatures were recorded and throat swabs were taken; nasal swabs were also obtained from those given the spray. The swabs were broken off into 5-ml. bottles containing $0.5 \%$ lactalbumin in Hanks's balanced salt solution with $0.02 \%$ sodium bicarbonate added. The bottles were stored and transported to the laboratory on melting ice.

Blood samples were taken from volunteers with antibody two weeks after vaccination. Volunteers initially without antibody had blood taken immediately before the second dose of vaccine, and a final blood sample two weeks later. The blood specimens were stored at $4^{\circ} \mathrm{C}$. until taken to the laboratory for separation of the serum.

A careful record was kept of any respiratory illnesses on the station and among the family contacts of the volunteers. A throat swab and paired serum specimens were taken for laboratory examination from all patients admitted to sick quarters with acute respiratory illness.

\section{Results}

The number of volunteers who received each type of vaccine and the symptoms of which they complained after vaccination are shown in Table II. Fever was observed in only one person. a man without neutralizing antibody who developed a mild influenza-like illness. He had received $10^{5} \mathrm{EID}_{50}$ of the $\mathrm{A} / \mathrm{Scot} / 49 / 57$ vaccine, and his symptoms lasted 48 hours. Mild afebrile coryzal symptoms were recorded in 38 of the 96 $(40 \%)$ volunteers without antibody and 5 of the $55(9 \%)$ with antibody. There was little evidence that these rates were related to the type of vaccine, the dose, or the method of administration. After the challenging dose 66 of the $75(8 \%)$ had coryzal symptoms.

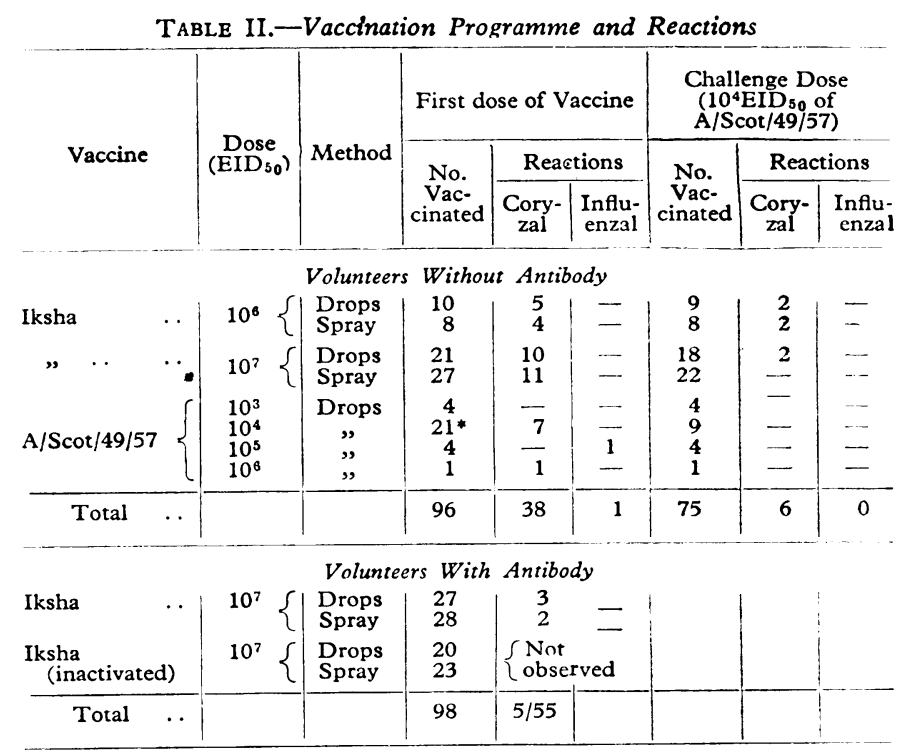

* Including 11 who were vaccinated at the same time as the others were given the challenge dose and who were not themselves challenged.

\section{Virus Isolation}

The results of virus isolation tests are shown in Table III. Influenza virus was isolated from 1 of the $27(4 \%)$ men with neutralizing antibody given the Iksha vaccine by drops at $10^{7} \mathrm{EID}_{50}$, and from none of the 28 men who were sprayed. 
Virus was isolated from 9 of the $35(26 \%)$ men without antibody who were sprayed, from 10 of the $31(32 \%)$ men who received Iksha vaccine by drops, and from 5 of the $30(17 \%)$ who were given various doses of $\mathrm{A} / \mathrm{S} \cot / 49 / 57$ vaccine by drops. After the challenge dose of $\mathrm{A} / \mathrm{S} \cot / 49 / 57$ vaccine virus was recovered from 4 of the $75(5 \%)$ men. There was little evidence to show that the route of administration influenced virus isolation results, and the same was true of vaccine dose. The recovery rate of virus after challenge was much lower than after the primary dose ; but as different vaccines were used this finding must be interpreted with caution.

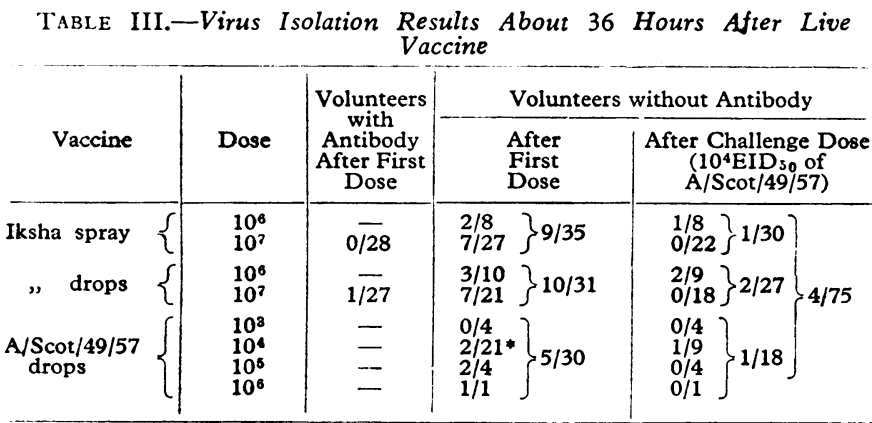

* Including $1 / 11$ volunteers who were vaccinated at the same time as others were given the challenge dose.

\section{Serological Tests}

The findings of the serological investigations are summarized in Tables IV and V. The majority of volunteers without antibody showed no response to the Iksha vaccine by complementfixation or haemagglutination-inhibition tests, and there was little difference between drops and spray. The Scottish vaccine strain produced antibody in a considerably higher proportion of subjects, but the number in this group was not large.

In volunteers with antibody there was a sharp contrast between the results after drops or spray and those after live or inactivated vaccine. A high proportion $(63 \%)$ who received live vaccine by drops had a fourfold or greater rise by haemagglutination-inhibition, whereas only one volunteer from the other three groups showed a response. A further contrast lay between the haemagglutination-inhibition and complementfixation test findings; not a single rise of complement-fixing antibodies was observed.

Of all volunteers receiving Iksha drops 28 out of 84 (33\%) showed a fourfold or greater rise of antibody titre. This com-

TABLE IV.-Proportions of Volunteers Without Neutralizing Antibody Showing a Fourfold or Greater Rise in Antibody Titre Between First and Subsequent Bleedings

\begin{tabular}{|c|c|c|c|c|c|c|}
\hline \multirow[t]{2}{*}{$\begin{array}{l}\text { Weeks after } \\
\text { First Dose }\end{array}$} & \multicolumn{2}{|c|}{$\begin{array}{c}\text { Iksha Spray } \\
\left(10^{6} \text { or } 10^{7} \text { EID }_{50}\right)\end{array}$} & \multicolumn{2}{|c|}{$\begin{array}{c}\text { Iksha Drops } \\
\left(10^{6} \text { or } 10^{7} \text { EID }_{50}\right)\end{array}$} & \multicolumn{2}{|c|}{$\begin{array}{c}\mathrm{A} / \mathrm{S} \cot / 49 / 57 \\
\left(10^{3}-10^{6} \mathrm{EID}_{50}\right)\end{array}$} \\
\hline & H.I.* & C.F.t & H.I.* & C.F.t & H.I.* & C.F. $\dagger$ \\
\hline $\begin{array}{l}\text { Virus } \\
\text { isolated }\end{array}$ & $\begin{array}{l}1 / 7 \\
0 / 7\end{array}$ & $\begin{array}{l}0 / 7 \\
2 / 7\end{array}$ & $\begin{array}{l}3 / 10 \\
3 / 9\end{array}$ & $\begin{array}{l}1 / 10 \\
1 / 9\end{array}$ & $\begin{array}{l}2 / 5 \\
4 / 4\end{array}$ & $\begin{array}{l}3 / 5 \\
2 / 4\end{array}$ \\
\hline $\begin{array}{l}\text { Virus not } \\
\text { isolated }\end{array}$ & $\begin{array}{l}3 / 26 \\
6 / 24\end{array}$ & $\begin{array}{l}5 / 26 \\
6 / 24\end{array}$ & $\begin{array}{l}2 / 19 \\
3 / 19\end{array}$ & $\begin{array}{l}3 / 19 \\
1 / 19\end{array}$ & $\begin{array}{l}8 / 25 \\
6 / 14\end{array}$ & $\begin{array}{l}7 / 25 \\
3 / 14\end{array}$ \\
\hline Total & $\begin{array}{c}4 / 33 \\
(12 \%) \\
6 / 31 \\
(19 \%)\end{array}$ & $\begin{array}{c}5 / 33 \\
(15 \%) \\
8 / 31 \\
(26 \%)\end{array}$ & $\begin{array}{c}5 / 29 \\
(17 \%) \\
6 / 28 \\
(21 \%)\end{array}$ & $\begin{array}{c}4 / 29 \\
(14 \%) \\
2 / 28 \\
(7 \%)\end{array}$ & $\begin{array}{l}10 / 30 \\
(33 \%) \\
10 / 18 \\
(56 \%)\end{array}$ & $\begin{array}{c}10 / 30 \\
(33 \%) \\
5 / 18 \\
(28 \%)\end{array}$ \\
\hline
\end{tabular}

* Haemagglutination-inhibition. +Complement-fixation.

TABLE V.-Proportion of Volunteers with Neutralizing Antibody Showing a Fourfold or Greater Rise in Antibody Titre Two Weeks After Vaccination

\begin{tabular}{|c|c|c|c|c|c|}
\hline \multirow[t]{2}{*}{ Vaccine } & & \multicolumn{2}{|c|}{$\begin{array}{c}\text { Iksha Drops } \\
\left(10^{7} \text { EID }_{s_{0}} \text { in } 1 \mathrm{ml} .\right)\end{array}$} & \multicolumn{2}{|c|}{$\begin{array}{c}\text { Iksha Spray } \\
\left(10^{7} \text { EID }_{5_{0}} \text { in } 0.1 \mathrm{ml} .\right)\end{array}$} \\
\hline & & H.I.* & C.F.t & H.I.* & C.F.t \\
\hline $\begin{array}{l}\text { Live vaccine } \\
\text { Inactivated vaccine }\end{array}$ & $\because$ & $\begin{array}{c}17 / 27(63 \%) \\
1 / 20(5 \%)\end{array}$ & $\begin{array}{l}0 / 27 \\
0 / 20\end{array}$ & $\begin{array}{l}0 / 28 \\
0 / 23\end{array}$ & $\begin{array}{l}0 / 28 \\
0 / 23\end{array}$ \\
\hline
\end{tabular}

pares poorly with a similar population given inactivated vaccine (Hobson et al., 1964), when 44 out of $54(81.5 \%)$ produced a significant response.

\section{Respiratory Illness in Other Personnel}

There was very little respiratory illness on the station during the period of the trial. Between the time that vaccine was first given at the end of October and the end of the year only eight R.A.F. personnel were admitted to sick quarters with a febrile respiratory illness. Paired sera from these patients were examined by complement-fixation tests for evidence of infection with influenza viruses $A$ and $B$, adenovirus, psittacosis virus, and Coxiella burnesti. Three showed a fourfold or greater rise in titre against influenza virus $B$ and the remainder were negative.

\section{Discussion}

Fairly clear answers were obtained to most of the questions for which the investigation was designed. Vaccine prepared from the Scottish strain apparently immunized volunteers as effectively as the widely used Iksha vaccine strain, and the reactions were no greater. Moreover, a dose of $10^{4} \mathrm{EID}_{50}$ of the British vaccine was at least equivalent to $10^{6} \mathrm{EID}_{50}$ of the Russian vaccine, as judged by serological or virus isolation tests. A finding of practical value was that the administration of vaccine by nasal spray-a very simple procedure-produced similar results to the cumbersome method of instilling nasal drops. The peculiar failure of spray to induce a response in persons already with antibody cannot be explained, but the experiment should be repeated before any conclusion is drawn from the observation. Certainly, inactivated vaccine given by either method was quite ineffective. On the other hand, the antibody responses observed were lower than those which follow intramuscular injection of inactivated virus.

This investigation has also indicated clearly our essential ignorance of what is involved in the preparation and use of live influenza vaccines. Although the Iksha vaccine was prepared in exactly the same way as that used in the 1960 trial (McDonald et al., 1962), the frequency of virus recovery and the antibody responses were much inferior. Perhaps changes with passage of time in some characteristic of the virus strain or the human population, or both, accounted for this. Unfortunately there are no laboratory tests available by which the ability of vaccine strains to multiply in or to damage cells of the human respiratory tract can be detected and compared, and so this kind of question cannot be answered at present. The British strain, picked more or less at random, behaved in a similar manner to the carefully selected Iksha strain, but we cannot conclude that it was sufficiently " attenuated" for safe use on a large scale. The nature and stability of the " attenuation" produced by a small number of egg passages is not known. More reactions might have occurred if the dosage of virus given had been as large as the dose of Iksha ; the failure to spread and cause illness may have been partly due to good fortune and partly to the high prevailing level of natural immunity in the population.

The potential importance of a live influenza vaccine and the encouraging results from trials such as ours appear to warrant intensive laboratory study of the characteristics by which stable and avirulent virus strains can be recognized.

\section{Summary}

Two live influenza-A vaccines were given to 96 volunteers without neutralizing antibody. The Russian Iksha strain was given in doses of $10^{6}$ or $10^{7}$ egg-infectious doses $\left(\mathrm{EID}_{50}\right)$ to 66 
volunteers, and a British strain in doses ranging from $10^{3}$ to $10^{6} \mathrm{EID}_{50}$ to 30 volunteers. One month later 75 of the vaccinated volunteers were given $10^{4} \mathrm{EID}_{50}$ of the British vaccine. In addition, 55 volunteers with neutralizing antibody were given $10^{7} \mathrm{EID}_{50}$ of the Iksha vaccine by drops or spray, and 53 volunteers were given the same dose of vaccine inactivated with formalin.

Of the volunteers without antibody $41 \%$ had mild respiratory symptoms after the first dose, and $8 \%$ after the challenging dose ; $9 \%$ of the volunteers with antibody who were given live vaccine had similar symptoms.

Virus was recovered from $25 \%$ of the volunteers without antibody after the first dose of vaccine, and from $5 \%$ after the challenging dose. Immediately before the challenging dose of vaccine $21 \%$ of the volunteers showed fourfold or greater haemagglutination-inhibition antibody response and $21 \%$ a complement-fixation response; two weeks after the challenging dose the proportions were $29 \%$ and $19 \%$ respectively. A much higher proportion of volunteers showed an antibody response after live than after inactivated vaccine.
A dose of $10^{4}$ EID $_{50}$ of the British vaccine gave similar results to that of $10^{6}$ or $10^{7} \mathrm{EID}_{50}$ of the Iksha vaccine. Except perhaps in volunteers with antibody there was little difference in efficacy of administration by nasal drops or spray.

We thank the volunteers of the Common Cold Research Unit, Salisbury, and at R.A.F. Technical College, Henlow, without whom these studies could not have been carried out. We are grateful to Dr. M. L. Bynoe and Miss E. Bullock, S.R.N. (Salisbury), and the Medical Officers at R.A.F. Henlow for their valuable help. We are indebted to the Director-General of the Royal Air Force Medical Services for the facilities to carry out this trial, and for permission to publish this report.

\section{REFERENCES}

Beare, A. S. (1962). Mth. Bull. Minist. Hlth Lab. Serv., 21, 167. Bradstreet, C. M. P., and Taylor, C. E. D. (1962). Ibid., 21, 96.

Hobson, D., Lane, C.. A., Beare, A. S., and Chivers, C. P. (1964). Brit. med. $\ddot{7}, 2,271$.

McDonald, J. C., Zuckerman, A. J., Beare, A. S., and Tyrrell, D. A. J. (1962). Ibid., 1, 1036.

Przesmycki, F., Sawicki, L., and Dobrowolsta, H. (1959). Bull. Wla Hlth Org., 20, 333.

\title{
Extensive Histological and Cytological Survey of Patients with Acute Leukaemia in "Complete Remission"*
}

\author{
G. MATHÉ, PR.AGR.FAC.MÉD., PARIS ; L. SCHWARZENBERG, D.M. ; A. M. MERY. D.M. \\ A. CATTAN, D.M., M. SCHNEIDER, D.M.; J. L. AMIEL, D.M.; J. R. SCHLUMBERGER, D.M. \\ J. POISSON, D.M. ; G. WAJCNER, D.M.
}

[With Special Plate]

Brit. med. F., 1966, 1, 640-642

Throughout the world only about 50 patients with acute leukaemia have had a remission lasting longer than five years (Burchenal and Murphy, 1965). In most patients with this disease the remissions that are called "complete" are invariably followed by a recurrence.

It can be questioned whether this recurrence is due to proliferation of the leukaemic cells that have persisted and whose presence has not been detected on routine examination. On the other hand, it is possible that the original leukaemic cells are destroyed and that the recurrence is due to the induction of a new leukaemia by a leukaemogenic factor which remains in the body. It would therefore be logical to obtain very detailed information about the state of the leukaemic cells during a so-called complete remission.

In practice we have made the following observations on patients during a remission:

1. A study of the cells present in the blood by means of a leucoconcentration technique (this had previously been shown to be able to demonstrate circulating cancer cells in patients with haematosarcomata who were not leukaemic (Festing, 1962)).

2. A cytological examination of six bone-marrow biopsies and a histological examination of one. (Bernard and Mathé (1951) have shown that when multiple bone-marrow biopsies are taken simultaneously from patients with acute leukaemia the cellular picture may vary from site to site.) The skeleton is also examined radiologically.

- Institut de Cancérologie et d'Immunogénétique, Hôpital Paul-Brousse, and Service d'Hématologie de l'Institut Gustave-Roussy, Villeiuif, Seine.
3. The central nervous system is examined by an analysis of the cerebrospinal fluid and by electroencephalography; there is a high frequency of leukaemic infiltration of the meninges and central nervous system during the course of an acute leukaemia (Wells and Silver, 1957).

4. Biopsies are taken from the kidney, liver, and testicles (see Special Plate).

In those patients in whom the investigations revealed the presence of leukaemic cells, the treatment which has led to the remission is continued at twice the dosage for a month. This treatment is generally with corticosteroids. After this period, those tests that revealed the presence of leukaemic cells are repeated.

\section{Methods, and Patients Studied}

The methods used for this investigation start when the patient's routine blood count and bone-marrow are found to be in the normal range both quantitatively and qualitatively. Thirty-one patients were studied in the present survey; details of their age, sex, classification according to cell type involved, history of the proliferative phase preceding the remission, and treatment during the proliferative phase are given in Table I.

The technique used in counting the leukaemic blast cells after concentrating the blood is as follows: $30 \mathrm{ml}$. of blood is taken into A.C.D. (acid-citrate-dextrose, 1 vol. A.C.D. for 9 vol. blood) and allowed to stand at an angle of 45 degrees for three hours. The supernatant plasma containing the leucocytes is then removed and its volume measured. This supernatant is 